\title{
Les défis et le rôle de doyenne dans l'avancement de la qualité de la formation infirmière / Challenges and the role of Dean in advancing quality nursing education
}

Jacinthe I. Pepin

Université de Montréal, jacinthe.pepin@umontreal.ca

Florence Myrick

amyrick@ualberta.ca

Follow this and additional works at: https://qane-afı.casn.ca/journal

Part of the Educational Administration and Supervision Commons, Educational Leadership Commons, Higher Education Commons, and the Nursing Commons

\section{Recommended Citation}

Pepin, Jacinthe I. and Myrick, Florence (2015) "Les défis et le rôle de doyenne dans l'avancement de la qualité de la formation infirmière / Challenges and the role of Dean in advancing quality nursing education," Quality Advancement in Nursing Education - Avancées en formation infirmière: Vol. 1: Iss. 2, Article 7.

DOI: https://doi.org/10.17483/2368-6669.1043

This Interview is brought to you for free and open access by Quality Advancement in Nursing Education - Avancées en formation infirmière. It has been accepted for inclusion in Quality Advancement in Nursing Education - Avancées en formation infirmière by an authorized editor of Quality Advancement in Nursing Education - Avancées en formation infirmière. 
Les défis et le rôle de doyenne dans l'avancement de la qualité de la formation infirmière

Interviewée: Dre Francine Girard, professeure agrégée et doyenne, Faculté des sciences infirmières, Université de Montréal.

Interviewer: Dre Jacinthe Pepin, Co-rédactriceen-chef

Dre Pepin : Quelle est votre vision de la situation actuelle de la formation infirmière au Canada?

Dre Girard: Il est très difficile d'avoir une vision de l'ensemble de la formation infirmière au Canada car ce sont les provinces qui décident des orientations spécifiques, en prenant en compte celles des ordres professionnels. De son côté, l'Association canadienne des écoles de sciences infirmières (ACÉSI) met de l'avant des approches pour une certaine harmonisation entre les provinces. Ceci étant dit, quand on regarde ce qui se fait actuellement, on se rend compte que plusieurs méthodes d'enseignement sont utilisées et que les curricula prennent différentes formes. À mon avis, les enseignements dans les programmes doivent se rapprocher des besoins de santé de la société et j'avoue ne pas être certaine que ce soit toujours le cas.

En général au Canada, et cela est inquiétant, l'attention est portée sur la pénurie infirmière en milieu clinique mais il existe aussi une pénurie dans les milieux académiques, notamment, de personnes préparées au doctorat pour enseigner à tous les cycles universitaires. Le pourcentage d'infirmières qui détiennent un doctorat n'est pas très élevé (4.2\% des infirmières canadiennes détiennent une maîtrise ou un doctorat ${ }^{\mathrm{i}}$ - aucun $\%$ spécifique au $\mathrm{PhD}$ n'a été trouvé. Ainsi, les universités n'ont pas vraiment été en mesure de prévoir l'augmentation des effectifs étudiants pour contrer la pénurie d'infirmières cliniciennes. En fait, les programmes universitaires semblent former le même nombre d'étudiants qu'il y a une quinzaine d'années. En plus, ce qui m'inquiète
Challenges and the role of Dean in advancing quality nursing education

Interviewee: Dr. Francine Girard, Associate Professor and Dean of the Faculty of Nursing, Université de Montréal

Interviewer: Dr. Jacinthe Pepin, Co-Editor in Chief

Dr. Pepin: How do you see the current status of nursing education in Canada?

Dr. Girard: It's very hard to form an overall impression of nursing education in Canada because decisions regarding specific orientations are made by the provinces, taking into account the orientations of the professional associations. The Canadian Association of Schools of Nursing (CASN) is advocating approaches that would allow harmonization between the provinces. That said, when you look at how things currently work, it's clear that several different teaching methods and curricula are being used. In my opinion, teaching in nursing programs should be aligned with the health needs of society, and I admit I can't say this is always the case.

Generally in Canada - and this is worrisome attention is focused on the shortage of nurses in the clinical setting, but there is also a shortage in the academic setting, in particular for doctorally prepared faculty at all university levels. Since the percentage of nurses with $\mathrm{PhDs}$ is not very high (4.2\% of Canadian registered nurses hold master's or $\mathrm{PhD}$ qualifications ${ }^{i}$ - no stand-alone percentage for $\mathrm{PhDs}$ could be located), universities have not been equipped to accommodate the increase in enrolment needed to address the clinical nursing shortage. In fact, university programs appear to be educating the same number of students as they were about fifteen years ago. Another thing that concerns me, as dean, is the student retention rate in nursing programs, which is staying down around $70 \%$, while CNA data for $2011^{i i}$ predict a 
comme doyenne, c'est le taux de persévérance aux études en sciences infirmières, qui se maintient seulement autour de $70 \%$, alors que, selon les données de 2011 de l'AIIC ii , il est prédit qu'il manquera, 60000 infirmières ETP en 2022. Donc, la situation actuelle n'est pas optimale.

De plus, à ma connaissance, l'enseignement de type magistral est encore l'approche la plus répandue dans les programmes dans notre pays même si l'apprentissage par problèmes existe depuis plusieurs années. Et l'approche par compétences est encore moins répandue. Ce qui est nommé l'apprentissage par compétences n'est pas nécessairement l'approche qui est imprégnée dans l'ensemble du programme, comme on l'entend ici. Puis, il existe de nombreuses autres méthodes: en ligne, délocalisation, méthodes hybrides. Donc, c'est un peu un méli-mélo qui fait qu'un baccalauréat dans une province n'est pas essentiellement le même dans une autre.

Dre Pepin: Plus spécifiquement en tant que doyenne, quel est votre rôle au regard de l'avancement de la qualité en formation infirmière?

Dre Girard : En tant que doyenne, je dois avant tout m'assurer de la qualité des programmes dans mon université et m'assurer du transfert de cette qualité vers la formation clinique avec nos milieux partenaires. Je crois fermement qu'une université a la responsabilité d'établir des collaborations avec ses milieux cliniques pour s'assurer que les besoins de santé sont rencontrés, mais bien entendu, tout en respectant les besoins académiques. Donc pour moi, le partenariat est primordial. Il faut soutenir le développement des habiletés des préceptrices en milieux cliniques à encadrer nos étudiantes. Je crois que l'apprentissage en stages est aussi important que l'apprentissage de la théorie en milieux académiques; l'un ne va pas sans l'autre. L'investissement financier pour l'encadrement en stages demeure toutefois un grand défi.

Le milieu universitaire a la responsabilité de préparer des professionnels de la santé mais aussi pour faire de la recherche ou de préparer la relève shortage of 60,000 FTE nurses by 2022 . So the current situation is not optimal.

Also, to my knowledge, lecture-type teaching is still the method most commonly used in nursing programs in our country, even though problembased learning has existed for several years. And the competency-based approach is even less commonly used. What is referred to as competency-based learning is not necessarily embedded throughout the program, as we understand it here. And there are many other models: online, off-campus, hybrid formats. So it's a bit of a hodgepodge, which means that a bachelor's degree in one province is not fundamentally the same as one in another province.

Dr. Pepin: More specifically, what role do you play as dean in quality advancement in nursing education?

Dr. Girard: As dean, my first duty is to ensure the quality of the programs at my university, and to make sure this quality is transferred to the clinical education at our partner agencies. I firmly believe that a university has the responsibility to work in collaboration with its clinical settings to ensure that health needs are met, while at the same time accommodating academic needs. So for me, partnerships are essential. We need to support the development of preceptors' skills in educating our students in a clinical setting. I think placement-based learning is as important as theoretical or academic learning; the two go hand in hand. The financial investment for placement-based education is still a big challenge.

Universities have the responsibility of preparing qualified health professionals but they also have the responsibility of doing research and preparing the next generation of researchers. In my view, what I would call basic research is as important as applied research. What I mean is, researchers must address clinical problems but they must also carry out fundamental research that is not as directly applicable in health care settings. Research into teaching methods is one 
en recherche. Je crois en l'importance de la recherche que j'appellerai de base tout autant que la recherche appliquée. Je veux dire que les chercheurs doivent répondre à des questions cliniques mais qu'ils doivent aussi réaliser des recherches de type fondamental, moins directement utiles dans les milieux de soins. La recherche sur les méthodes pédagogiques est un exemple. Il importe aussi d'en évaluer les retombées pour les soins aux personnes.

Dre Pepin : Donc, vous voyez le rôle de doyenne, à la fois dans le milieu universitaire mais aussi en partenariat avec les milieux cliniques pour assurer une formation académique et clinique de qualité. Puis vous voyez l'importance de la recherche.

Dre Girard : Oui, je crois que ce sont les deux responsabilités les plus importantes d'une doyenne. Ensuite, il faut que notre faculté rayonne aux plans local, provincial, national et international. Nous avons tous la responsabilité de partager nos savoirs et de faire des partenariats avec d'autres milieux car personne n'a la connaissance absolue. C'est en discutant avec d'autres et en partageant nos savoirs, qu'on pourra faire avancer la qualité. En tant que doyenne d'une faculté dans une université de recherche, je crois aussi qu'il est essentiel d'influencer les processus décisionnels à l'université et j'oserais dire d'influencer les processus décisionnels gouvernementaux.

Dre Pepin : Vous insistez donc sur l'importance d'exercer du leadership à différents niveaux.

Dre Girard: J'ajouterais qu'il ne faut jamais oublier que c'est le patient qui est le plus important - la personne, sa famille, leurs expériences de santé - et dans nos milieux de formation, ce sont aussi nos étudiants. Est-ce que c'est toujours le cas? Je ne suis pas certaine, mais ça devrait l'être. Donc, leur expérience d'apprentissage, la qualité de leur programme et en particulier celle de l'encadrement clinique sont des éléments majeurs de leur formation. Et puis, j'oserais ajouter l'importance de la technologie en 2015, afin de reconnaître les besoins de la jeune génération d'étudiants quant à différentes example. It is also important to evaluate the impact of the various educational methods on health care delivery.

Dr. Pepin: So you see the role of dean, in both the university setting and in partner clinical settings, as ensuring quality academic and clinical education. And you recognize the importance of research.

Dr. Girard: Yes, I think those are the two most important responsibilities of a dean. Then there's the need to ensure that our faculty has a presence and an influence locally, provincially, nationally and internationally. We all have the responsibility of sharing our knowledge and building partnerships with other communities, because no one has absolute knowledge. It is only by exchanging ideas and sharing our knowledge that we can succeed in advancing quality. As dean of a faculty in a research university, I also think it is essential to influence the university's decision-making processes and, I would venture to say, government decisionmaking processes as well.

Dr. Pepin: So you stress the importance of exercising leadership at different levels.

Dr. Girard: Let me add, we must never forget that what comes first is the patient - the person, their family, their health care experiences - and, in our educational settings, our students. Is this always the case? I can't say for sure, but it should be. So, our students' learning experience, the quality of their program and of their clinical practice in particular, are key elements in their education. And I would even add the importance of technology in 2015, to acknowledge the needs of the young generation of students regarding the different teaching models that can be used to reach them.

Dr. Pepin: Would you care to expand a bit on technology and its impact on nursing education?

Dr. Girard: There are debates nowadays in various academic circles about the pros and cons of classroom-based courses and electronic or distance courses using videoconferencing or 
approches pédagogiques par lesquelles on peut les rejoindre.

Dre Pepin : Voulez-vous en parler un peu de la technologie et de son impact sur la formation?

Dre Girard : À l'heure actuelle, il y a des débats dans plusieurs milieux académiques entre les cours en présentiel et les cours en numérique ou à distance, via visioconférence ou autres, mais la nouvelle génération ne vit que par ces technologies. Et je pense que les universités qui ne réussiront pas à s'établir dans ces marchés vont perdre beaucoup de clientèles. Est-ce qu'il faut établir des mécanismes pour les utiliser de façon beaucoup plus réfléchie? Je crois que oui. Ce sont des cours et programmes coûteux à développer et à maintenir mais je pense qu'il faut réviser nos façons de penser et cela influencera la qualité de la formation. Aussi, dans les milieux cliniques, il $\mathrm{y}$ a un accès de plus en plus grand à des technologies variées et si on n'habitue pas nos étudiants à pratiquer leur profession avec l'aide de ces outils, je pense qu'on aura failli dans la façon de les former pour le futur.

Dre Pepin : Quel est, selon vous, le plus grand défi auquel la formation infirmière fait face aujourd'hui, particulièrement dans le contexte Canadien?

Dre Girard : C'est une question assez difficile à répondre, parce qu'à mon avis, il y a plusieurs niveaux de défis qui affectent la formation en sciences infirmières. Je commencerai avec un niveau très élevé, celui des cycles de gestion des gouvernements, des universités, des facultés et des milieux cliniques. À chaque cycle, il y a un changement de vision et de priorités et c'est très difficile de mener des changements dans des programmes qui sont en cours, car bien entendu avec chaque cycle vient aussi la question des ressources financières. De plus en plus, à la grandeur du Canada, il y a des coupures en éducation et en santé. Donc, d'un côté, il faut préparer nos étudiants avec des programmes constamment mis à jour, basés sur les résultats probants et qui répondent aux besoins de la société. De l'autre côté, nous n'avons pas les other means. But for the new generation, life revolves around these technologies. In my opinion, universities that fail to establish a presence in these markets will lose a lot of their potential students. Do we need to establish mechanisms to use these technologies more effectively? I think so. These types of courses and programs are costly to develop and maintain but I believe we have to change our way of thinking, and that will impact the quality of education. Also, in clinical settings there is more and more access to different kinds of technology, and if our students aren't acquainted with the use of these tools in practice, I believe we will have failed in preparing them for the future.

Dr. Pepin: In your opinion, what is the biggest challenge facing nursing education today, particularly in Canada?

Dr. Girard: That's a pretty tough question to answer, because I believe the challenges facing nursing education originate at several different levels. First, at a very high level are the management cycles of governments, universities, faculties and clinical settings. With each new cycle comes a new vision and new priorities, and it's very hard to make changes to existing programs because each cycle means, of course, revisiting the issue of financial resources. Across Canada, there are more and more cuts in education and health. So on one hand, we need to prepare our students using continually updated, evidence-based programs that meet the needs of society. On the other hand, we don't have the financial means or the doctorally prepared human resources to do this. So for me, this is a major challenge.

An even greater challenge, and I'm not sure how to say this in politically correct terms, is that at present, there is a lack of leadership in the nursing community capable of influencing decision-making processes before it is too late. This worries me a lot. For example, university nursing faculties are small to medium-sized faculties lost in a sea of other faculties that generally have more power. So, once again, it is 
outils financiers ni les ressources humaines préparées avec $\mathrm{PhD}$ pour le faire. Donc pour moi c'est un défi majeur.

Ce qui est un défi encore plus grand, et je ne sais pas comment le dire pour que ce soit politiquement acceptable, c'est qu'à l'heure actuelle, il y a un manque de leadership du monde infirmier capable d'influencer les processus décisionnels avant qu'il ne soit trop tard. Cela m'inquiète énormément. Par exemple, dans les universités, les facultés de sciences infirmières sont des facultés de moyenne à petite taille et elles sont perdues dans une mer d'autres facultés qui ont en général plus de pouvoirs que les facultés de sciences infirmières. Donc, il est essentiel, ici aussi, d'établir des partenariats avec les autres facultés de la santé, les autres facultés en général, et particulièrement avec le rectorat et les vicerectorats, parce que c'est là que les décisions budgétaires sont prises.

Ce qui est inquiétant en sciences infirmières, c'est la difficulté incroyable que nous avons à unifier notre discours et à être capables de nous regrouper derrière des priorités, un plan stratégique qui ferait avancer la profession. Des milieux cliniques aux universités, aux ordres professionnels, il existe une difficulté énorme à s'entendre sur les priorités que nous devrions mettre de l'avant. Donc pour le Canada en général, c'est une question assez difficile à répondre, parce que les décisions sont prises à différents niveaux et que ce n'est pas certain que nous allons rencontrer les mêmes défis et identifier les mêmes priorités.

Dre Pepin: Donc, vous suggérez une concertation dans la profession autant qu'une influence politique à différents niveaux?

Dre Girard: Je suis une passionnée de la profession infirmière. En tant qu'infirmière, il faut que je sois capable d'articuler très clairement ce que j'apporte à l'équipe et préciser mon rôle au sein de l'équipe. Dans les milieux cliniques, le travail d'équipe est favorisé et il est préférable que l'équipe soit intégrée. La même chose prévaut en recherche parce qu'un chercheur doit s'associer à des chercheurs d'autres disciplines, essential that partnerships be established with other health faculties, other faculties in general, and especially with the offices of presidents and vice-presidents, because that's where the budget decisions are made.

What is very troubling in nursing education is the incredible difficulty we have trying to speak with one voice and standing together behind priorities, behind a strategic plan that would advance the profession. From clinical settings to universities to professional associations, it is a huge struggle to reach agreement on the priorities we should be setting. So as regards Canada overall, it's a fairly difficult question to answer, because the decisions are made at different levels and there is no certainty that we will encounter the same challenges and will identify the same priorities.

Dr. Pepin: So you suggest cooperation within the profession and political influence at different levels?

Dr. Girard: I am passionate about the nursing profession. As a nurse, I must be able to clearly articulate what I bring to the team and spell out my role within the team. In clinical settings, teamwork is the favoured approach and it is best if the team is integrated. The same thing is true in research, because a researcher must collaborate with other researchers in other disciplines in order to increase his or her chances of securing funding. So it is becoming increasingly important to have a dialogue that clearly establishes the nursing position but is coupled with the positions of other professions to lobby for what we need, even in educational settings. For me, it is imperative that we think in terms of associating ourselves with other health professions in order to move certain projects forward and to demonstrate that the nursing profession is indispensable.

Dr. Pepin: What strategies have you or your Faculty used to address these challenges?

Dr. Girard: In our faculty, along with the executive committee members and several 
pour augmenter ses chances d'obtenir des fonds. Donc de plus en plus, il importe d'avoir un dialogue qui établit bien notre position infirmière mais qui s'attache à celles d'autres professions pour aller chercher ce dont nous avons besoin, même en milieux de formation. Pour moi, c'est essentiel de penser en termes d'association à d'autres professions de la santé, pour faire avancer certains projets et démontrer que la profession infirmière est incontournable.

Dre Pepin : Quelles sont les stratégies que vous ou votre faculté avez utilisées face à ces défis?

Dre Girard : Dans notre Faculté, avec les membres du comité de direction et plusieurs professeurs, nous influençons chacun à notre façon le développement des politiques régionales. Nous utilisons divers mécanismes d'influence, par exemple, auprès des ministères de la santé et des services sociaux (MSSS) et de l'éducation, enseignement supérieur, recherche et science (MESRS). Nous avons aussi établi des partenariats avec plusieurs collègues des universités canadiennes, fortes en recherche, pour échanger avec des étudiants au doctorat/postdoctorat, sur nos façons de faire. Nous avons réussi en tant que Faculté à établir de nouvelles collaborations, sur la scène internationale, surtout avec des pays francophones. Nous avons fait des percées en France, notamment, et maintenu de belles relations avec la Belgique et la Suisse. Avec le Liban, nous avons guidé la révision d'un programme de baccalauréat.

De plus, dans notre Faculté, nous avons donné préséance à la science de la formation infirmière, par l'ouverture en 2007, du Centre d'innovation en formation infirmière (CIFI), pour justement faire de la recherche sur la formation infirmière. Cela permettait de consolider les acquis de notre approche de formation par compétences mais aussi d'examiner d'autres façons d'enseigner à nos étudiantes. La pédagogie active est inscrite dans notre plan stratégique pour former la relève. En d'autres mots, nos étudiants mettent rapidement leurs connaissances théoriques en application dans des situations cliniques en professors, we all influence regional policy making in our own way. We use different mechanisms and channels of influence, for example through the provincial departments of health and social services (MSSS) and education, higher education, research and science (MESRS). We've established partnerships with numerous colleagues in other Canadian universities engaged in research for exchanges with doctoral/postdoctoral students on how we do things. Our faculty has also succeeded in developing new international collaborations, in particular in francophone countries. We have made significant inroads in France, and have good relations with Belgium and Switzerland. In Lebanon, we steered the redesign of a bachelor's program.

In addition, our faculty turned the spotlight on the science of nursing education with the 2007 launch of our new Centre for Innovation in Nursing Education (CIFI), specifically for research on nursing education. This has allowed us to consolidate what we have learned from our competency-based approach and to examine other methods of teaching our students. Active learning is a part of our strategic plan for educating the next generation. This means our students rapidly put their theoretical knowledge into practice in clinical situations in laboratory and health care settings. And they do the same in the classroom, working in teams on clinical case studies. So the focus is on applying knowledge as it is acquired.

To this end, the relationship with our nursing directors committee is essential. The directors keep us informed of education needs; for example, the need for new nurses to develop their ability to act professionally and to act humanely. We integrate all these elements into our teaching and we consult the directors on our strategic planning. As you know, we also evaluate our master's and doctoral programs, and the nursing directors are part of this process. So for us, this close association with clinical settings is absolutely key, especially when it comes to joining forces to present the needs of 
laboratoires et dans les milieux de soins. Et elles le font aussi en classe, par l'étude de situations cliniques en équipes. Donc, l'accent est mis sur l'application des connaissances au fur et à mesure des apprentissages.

Pour ce faire, la relation avec notre comité des directrices de soins infirmiers est essentielle. Les directrices font part des besoins de formation; par exemple, de développer les compétences agir avec professionnalisme et agir avec humanisme chez les nouvelles infirmières. Nous nous assurons de bien intégrer ensemble ces éléments dans la formation et nous les consultons pour nos planifications stratégiques. De plus, comme vous le savez, nous évaluons nos programmes de maîtrise et de doctorat. Les directrices des soins infirmiers font partie de ce processus. Donc, pour nous, cette alliance avec les milieux cliniques est absolument essentielle, en particulier, pour présenter ensemble les besoins de la profession infirmière aux instances décisionnelles. La force du message est multipliée quand il ne vient pas que du monde académique mais aussi des cliniciennes expertes directrices des soins infirmiers, que ce soit à la table nationale sectorielle, à l'OIIQ ou dans les appareils gouvernementaux.

Dre Pepin : Aussi, par la formation, il y a la possibilité d'influencer les soins pour le futur.

Dre Girard : Absolument. Par exemple, à l'Université de Montréal, nous avons des cours spécifiques pour développer la collaboration interprofessionnelle au premier cycle. Trois cours communs de un crédit offerts à l'ensemble des étudiants du domaine de la santé sont inclus dans tous les programmes. Ce qui m'interpelle encore davantage c'est notre approche humaniste qui amène les étudiantes à se centrer sur l'expérience de la personne et de sa famille malgré les contraintes. Notre responsabilité, c'est de préparer nos diplômées pour leur transition vers les milieux de soins.

Dre Pepin : Donc ce sont les stratégies utilisées. Pour terminer, une dernière grande question : À quel point le leadership est-il important pour faire the nursing profession to decision-making authorities. The message carries far more weight if it comes not only from the academic community but also from expert clinicians and nursing directors, whether it's addressed to the national sectoral table on nursing, the OIIQ or government agencies.

Dr. Pepin: Also, through education there is the potential of shaping health care for the future.

Dr. Girard: Absolutely. For example, at the Université de Montréal, we have undergraduate courses on developing interprofessional collaboration. Three one-credit core courses are taken by all students in all health programs. What I find even more compelling is our humanistic approach, which leads students to focus on the experience of the person and the family despite constraining circumstances. Our responsibility is to prepare our graduates for their transition to health care settings.

Dr. Pepin: So those are the strategies used. In closing, I have one last big question: How important is leadership in advancing the quality of nursing education?

Dr. Girard: I have so much to say on this, I don't know where to start. First, it is imperative that we support the autonomy of the nursing profession, while embracing the interprofessional movement, of course. In my view, our autonomy is indisputable! To maintain it, we will have to change the culture of nursing education and the value placed on research, because there is still a tendency to base practice and education on tradition and habit rather than evidence. Furthermore, it is important that all nurses, from staff nurses on, be educated so as to develop their leadership skills. That is absolutely essential.

If there's one thing I've learned over the years, from the clinical setting to the university setting, it's that partnerships, be they clinical, administrative, academic, professional or political, are crucial! Nothing can be done by one person alone, that's for sure! So, nursing 
avancer la qualité de la formation infirmière?

Dre Girard : J'ai tellement de choses à dire làdessus, où commencer? D'abord, il est primordial de soutenir l'autonomie de la profession infirmière, tout en participant, bien entendu, au mouvement interdisciplinaire. Pour moi, notre autonomie c'est indiscutable! Pour la maintenir, il va falloir faire évoluer la culture de la formation en sciences infirmières et la valorisation de la recherche, parce qu'encore trop souvent, la pratique et la formation sont basées sur la tradition et l'habitude plutôt que sur des résultats probants. En plus, il importe de former toutes les infirmières pour qu'elles développent leur leadership, en commençant par l'infirmière au chevet, c'est absolument essentiel.

S'il y a une chose que j'acquis à travers les années, du milieu clinique au milieu universitaire, c'est que les partenariats cliniques, administratifs, académiques, professionnels et politiques : sont indubitables! Rien ne peut être fait par une seule personne, c'est certain! Donc, la formation infirmière doit avoir une position unique et claire, de la part des directions universitaires, des ministères et des institutions cliniques. Si la profession n'est pas valorisée, comme discipline ayant ses savoirs, ce sera très difficile d'aller de l'avant dans le continuum formation et pratique. C'est la seule façon par laquelle l'autonomie et l'imputabilité de la profession pourront être assurées.

Je pense qu'il faut trouver des mécanismes par lesquels les infirmières seront mieux préparées pour influencer les décisions des ministères, des ordres professionnels, des milieux de l'éducation et des milieux cliniques. Il faudrait établir une direction stratégique et des objectifs communs pour les institutions cliniques et académiques, au plan régional. Au niveau canadien, peut-être que certains éléments stratégiques devraient rassembler toutes les universités et leur permettre d'avancer ensemble. En fait, nous assurer que les décisions affectant la formation infirmière et la prestation des soins soient basées sur des résultats probants et les meilleures pratiques, et prises ou education must hold a unique and clear position, for university administrations, government departments and clinical institutions. If the profession is not appreciated, as a discipline with its own body of knowledge, it will be very difficult to move forward in the education-topractice continuum. It's the only way of ensuring the autonomy and accountability of the profession.

I think mechanisms need to be found to ensure that nurses are better equipped to influence decisions made by government bodies, professional associations, academic settings and clinical settings. There is a need for a common strategic direction and shared objectives for clinical and academic institutions at the regional level. Canada-wide, it may be that universities should be united in some strategic elements so they can move forward together. Above all, we need to make sure that decisions affecting nursing education and the delivery of care are based on evidence and best practices, and that they are made or influenced by nurses. I'm emphatic about that.

We must continue to create and maintain contacts with decision-making authorities. We have to be there before any decision is made. I think we need to find a way to rapidly address regional and national priorities for health care and education, because the people in charge change and the mechanisms are complex. I believe we need to have the courage to explore different approaches and different models, ensure continuing development of nursing skills, and demonstrate flexibility in our educational approaches combining practice and theory, while strengthening the ongoing participation of clinical settings in educating tomorrow's nurses. I believe we will also have to think about our capacity to deliver programs that meet the needs of society and of the nursing profession, as well as the expectations of our students.

Leadership in education must be forwardlooking, present a unified and integrative vision, and demonstrate values that include mutual 
influencées par des infirmières. J'insiste.

Il faut continuer de créer et de maintenir des liens avec les instances décisionnelles. Il faut être là avant que la décision soit prise. Je crois, qu'il faut trouver une façon de répondre rapidement aux priorités de santé et de formation régionales et nationales, car les personnes changent de position et les mécanismes sont complexes. Je pense qu'il va falloir avoir le courage d'explorer différentes approches et différents modèles, assurer un développement continu des compétences des infirmières et démontrer de la flexibilité dans nos approches de formation reliant pratique et théorie, tout en renforçant la participation soutenue des milieux cliniques à la formation des infirmières et infirmiers du futur. Je pense par ailleurs qu'il faudra vraiment réfléchir sur nos capacités d'offrir des programmes qui répondent aux besoins de la société, à ceux de la profession infirmière mais aussi aux attentes de nos étudiantes.

Le leadership en formation devra être axé sur l'avenir, proposé une vision unifiée et transversale et démontré des valeurs dont le respect mutuel entre les milieux cliniques, académiques et politiques.

Dre Pepin : L'entrevue est terminée. Aimeriezvous ajouter quelque chose pour conclure?

Dre Girard: Être doyenne d'une faculté des sciences infirmières c'est une responsabilité énorme. C'est la responsabilité de s'assurer de rencontrer toutes les exigences dont nous avons discutées. C'est aussi de développer notre corps professoral, de soutenir les nouveaux professeurs pour qu'ils avancent dans leur carrière et d'appuyer ceux qui sont plus avancés, afin que chacun ait les capacités de réussir aux concours de fonds de recherche, alors que cela devient de plus en plus difficile. Il y a moins de Chaires de recherche en sciences infirmières que dans d'autres disciplines, c'est donc essentiel de recourir à la philanthropie, ce qui n'est pas chose facile en sciences infirmières.

Une doyenne est aussi bonne que l'équipe avec qui elle travaille et que l'appui qu'elle reçoit, de respect between clinical, academic and political players.

Dr. Pepin: That concludes the interview. Is there anything you'd like to add?

Dr. Girard: Being dean of a faculty of nursing is a huge responsibility. It involves meeting all the requirements we've discussed. It also involves developing the faculty members, supporting new professors to help them advance in their careers and supporting those who are already more advanced, so that each has the capacity to successfully compete for research funding at a time when it is becoming increasingly difficult to secure. There are fewer research chairs in nursing than in other disciplines, so that means relying on philanthropy, which is not an easy task in nursing.

A dean is as good as the team she works with and the support she gets, from her management team, the professionals who do the groundwork and the professors and sessional lecturers who give the best of themselves to educate the students. My favourite moment is when students give testimonials at the annual convocation! They have the ability to move me by their appreciation of the education they received, their desire to pursue higher studies and to make the patient the focal point of their professional lives - that touches me deeply. 
son équipe de direction, des professionnels qui font un travail de fond, des professeurs et des chargés de cours, qui donnent le meilleur d'euxmêmes pour former les étudiantes. Mon moment préféré est celui des témoignages des étudiantes à la collation annuelle des grades! Elles ont cette capacité de m'atteindre par la reconnaissance de la formation reçue, leur désir de continuer des études supérieures et de mettre le patient au centre de leur vie professionnelle, ça me touche profondément.

' Health Workforce Database, Canadian Institute for Health Information. 2013

ii Tested Solutions for Eliminating Canada's Registered Nurse Shortage, AllC, 2011 